\title{
Hematology of the freshwater fish, Notopterus notopterus in relation to Physico-chemical characteristics of the water
}

\author{
R. S. Kulkarni \\ Department of Zoology \\ Gulbarga University Kalburgi - 585 106, Karnataka, India \\ E-mail address: rskgug@gmail.com
}

Keywords: Haematology; Notopterus notopterus

ABSTRACT. Hematological and some biochemical contents of the blood in relation to physicochemical characteristics of the water have been studied in the fresh water fish, Notopterus notopterus. The results indicated that normal values have been found in comparison to the studies carried out in other fishes. Hence, the fish Notopterus notopterus is having favorable environmental temperature, $\mathrm{pH}$ and dissolved oxygen required for the fish to survive and regulate breeding activities.

\section{INTRODUCTION}

Blood biochemical and hematological studies on fishes have assumed greater significance due to the increasing emphasis on pisciculture and greater awareness of the pollution of natural freshwater resources in the tropics. Such studies have generally been used as an effective and sensitive index to monitor physiological and pathological changes in fishes (Iwama et al; 1976; Chekrabarty and Banergee, 1988).

The recommended methods presented in this report have included only well tested procedures and techniques for the determination of different hematological parameters. The values of different hematological parameters are found to influence significantly on the physiological condition, health and survival of the fish. Hence, it is necessary to assess the hematology of the fish from where the fish has been collected in relation to water quality. In the present study normal hematological profile of the freshwater fish, Notopterus notopterus collected from a particular aquatic body has been studied in relation to water quality.

\section{MATERIALS AND METHODS}

Live specimens of the Indian freshwater fish, Notopterus notopterus (about 30 fishes) were collected from Bheema river situated around $45 \mathrm{~km}$, away from Kalaburgi and transported in aerated containers to the laboratory. The fish were acclimatized for a week time feeding with earthworms, boiled eggs and small guppy fishes to avoid possible effect of starvation on any of the hematological parameters. The size of the fish varied from $26.5 \pm 1 \mathrm{~cm}$ in length and $105 \pm \mathrm{gm}$ in weight. All sexes were used without discrimination. The blood was collected from the caudal region with the aid of 2- $3 \mathrm{~cm}$ disposable plastic syringes and a 21 gangue disposable hypodermic needle and transferred to heparinised plastic containers. The samples were than mixed gently and thoroughly. Blood samples were used for the measurement of haematocrit, hemoglobin concentration and red blood cell count. Serum was obtained from blood by centrifugation and then drawn and used for the determination of total serum proteins and glucose.

The water samples were collected from Bheema river simultaneously during the fish collection and brought to the laboratory for determing dissolved oxygen and the other parameters such as $\mathrm{PH}$, temperature of the water was recorded at the site of collection by thermometer. The following methodology was adopted for blood analysis:-

1. Hemoglobin was measured using the standard cyanmethemoglobin method described by Baker and Silverton (1976). 
2.Total serum proteins were measured by using the modified Biuret method, arid end point assay described by Lawrence (1986).

3.Serum glucose was determined by GOD-POD end point assay method.

4.Packed call volume (PCV) hematocrite by micro method using capillary tube and centrifuged at $12000 \mathrm{rpm}$ for $5 \mathrm{~min}$ as described by the Wintrobe and Westergreen method. The red blood cells were enumerated in an improved Neubacur haemocytometer using method described by Dacie and Lewis (1984).

5.Urea and urea nitrogen are determined by modified Berthelot method.

The hematological indices: Mean corpuscular volume (MCV), mean corpuscular hemoglobin $(\mathrm{MCH})$ and mean corpuscular hemoglobin concentration $(\mathrm{MCHC})$ were determined from the following equations given by Wickham et al.,(1990).

$$
\begin{aligned}
& \operatorname{MCHC}(\%)=\frac{\text { Haemoglobin }}{\text { Haematosrit }} \times 100 \\
& \operatorname{MCH}(\mathrm{Pg})=\frac{\text { Haemoglobin }}{\text { Erythrocyte count }} \times 100 \\
& \operatorname{MCV}(\mathrm{fl})=\frac{\text { Haematocrit }}{\text { Erythrocyte count (per/l) }}
\end{aligned}
$$

The Physico-chemical parameters of Bheema river was undertaken by collecting water samples and determination of dissolved oxygen by modified winkler's method (APHA, AWWA, WCPF, 1985), $\mathrm{pH}$ by hand held digital $\mathrm{pH}$ meter and temperature by using ordinary mercury thermometer.

The data was analyzed statistically by adopting varied statistical methods. The student " $\mathrm{t}$ " test was carried out to know the levels of significance using the standard formula. All the values of $p$ below 5\% level are designated as significant and the above 5\% levels are designated as nonsignificant (Mungikar, 2003).

Table-1. Showing some Physico-chemical, hematological and biochemical parameters of the freshwater fish, N.notopterus collected from river Bheema near Kalaburgi.

\begin{tabular}{|l|l|l|}
\hline 1. & Dissolved oxygen & $10.9 \mathrm{mg} / 1$ \\
\hline 2. & PH & 8.4 \\
\hline 3. & Temperature & 30 0c \\
\hline 4. & RBC & $1.44 \pm 0.18$ millions $/ \mathrm{mm}^{3}$ \\
\hline 5. & Hb & $06.55 \pm 0.26$ \\
\hline 6. & HCT & $20.41+01.17$ \\
\hline 7. & MCV & $142.93+10.87$ \\
\hline 8. & MCH & $46.24+7.15$ \\
\hline 9. & MCHC & $32.20+2.60$ \\
\hline 10. & Glucose & $53.96+7.94$ \\
\hline 11. & Protein & $5.98 \pm 0.61$ \\
\hline 12. & BUN & $7.280 .+31$ \\
\hline 13 & Sodium & $88.49+10.68$ \\
\hline 14 & Potassium & $\underline{14.98+1.14}$ \\
\hline 15 & Calcium & $\underline{9.00+0.30}$ \\
\hline 16 & Phosphorous & $\underline{.0 .097+0.001}$ \\
\hline
\end{tabular}

The values are expressed as mean $+/-\mathrm{SD} \mathrm{N}=06$.

Statistical Significance: Erythrocytes $(\mathrm{RBC})$ count in millions $/ \mathrm{mm}^{3}-\mathrm{P}=0.01$, Hemoglobin $(\mathrm{Hb})$ in $\mathrm{g} / \mathrm{dl}$, , haematocrit (HCT) in \%, Mean cellular volume (MCV) in pg ,Mean cellular hemoglobin $(\mathrm{MCH}), \mathrm{P}<0.05$, Mean cellular hemoglobin concentration $(\mathrm{MCHC})$ in \%.BUN Blood urea nitrogen $\mathrm{mg} / \mathrm{dl}$. 


\section{OBSERVATION}

Hematological and blood biochemical parameters of the fish, Notopterus notopterus in relation to Physico-chemical characteristics of water has been studied to find out favorable conditions for survival and physiological activity.

The Physico-chemical parameters such as dissolved oxygen found to be optimum with $\mathrm{pH}$ values at the alkaline condition and temperature at a required level (Table-1).

Analysis of the peripheral blood of fish serves for diagnostic purpose to evaluate the condition and to assess the suitability of environmental condition. The blood cells represent a free connective tissue type, which neither maintain intimate connections with other cells, nor possess intercellular substances, constituting the homeostatic force of the organisms (Kalashnikova, 1976). The erythrocyte count (RBC) measures number of red blood cells present in the blood. The erythrocyte count found to be $1.44 \pm 0.18 \mathrm{million} / \mathrm{mm} 3$. The hemoglobin test is a measure of how much hemoglobin protein is present in the blood and it is found to be $6.55+0.26$ haematocrit is a blood test that measures the percentage of red blood cells found in the whole blood. This measurement depends on the number of red blood cells and the size of red blood cells. The data of hematocrite of this fish found to be $20.41 \pm 1.17$. The three indices are which are commonly used are, mean cell volume (MCV), mean cell hemoglobin $(\mathrm{MCH})$, mean cellular hemoglobin concentration (MCHC). The data for MCV: $142.93 \pm 10.87$, MCH-46.240 \pm 7.15 (pg) and MCHC: $32.20 \pm 2.60$, blood urea nitrogen (BUN) found to be $7.28 \pm 0.31$. The values found to be normal. The major function of the carbohydrates is to provide energy for the metabolic process. The blood glucose level found to be $53.96 \pm 7.94 \mathrm{mg} / \mathrm{dl}$. The serum protein found to be $5.98 \pm 0.61 \mathrm{~g} / \mathrm{dl}$.

The blood electrolytes which are sodium $\left(\mathrm{Na}^{+}\right)$, potassium $\left(\mathrm{K}^{+}\right)$, chloride calcium $\left(\mathrm{Ca}^{++}\right)$, and phosphorus $\left(\mathrm{P}^{+}\right)$are commonly used to determine the physiological characteristics, toxicity and health status of fish (Percin et al.,2010). The normal values are noticed for the fish, N.notopterus collcted from Bheema river presented in the table-01. Electrolyte $\left(\mathrm{Na}^{+}, \mathrm{K}^{+}, \mathrm{P}^{+}\right.$, and $\mathrm{Ca}^{++}$levels indicate the operation of a variety of homeostatic mechanisms in the body (Clarke, 1998). Sodium $\left(\mathrm{Na}^{+}\right)$, potassium $\left(\mathrm{K}^{+}\right)$and Chloride $\left(\mathrm{Cl}^{-}\right)$play an important role in osmoregulation and homeostasis.

\section{DISCUSSION}

Fish are useful as bio indicators of environmental changes ( Fausch et al;1990). The hematological studies have been considered as an important tool in the evaluation of physiological state and reflecting the relative health of the fish. The physical and chemical changes in aqueous environment often cause some physiological changes in fish, thus, the water quality of an aquatic body is very crucial because it determines the productivity and other parameters necessary for fish survival. Many countries have legislated against the use of chemical poisons in aquatic systems and instead have policies favoring the use of natural bio-degradable alternatives to remove unwanted fish species in aquatic systems. Environmental factors such as $\mathrm{pH}$, turbidity, alkalinity, dissolved oxygen, temperature and conductivity influence the rate of reaction of pollutants entering the water or the lethal effects on the aquatic organisms (Fagbenro, 2002). Water temperature affects all aspects of metabolism and at high temperatures metabolic rate increases alkalinity, acidity and $\mathrm{pH}$ determine fish health and the well-being of fish (Ross and Ross, 2002)

The blood parameters of the fish, N.notopterus collected from Bheema river in the present study indicates that, the values found to be normal as per reports available in other fishes. The aquatic body (Bheema river) also provides proper conditions for survival and breeding activities as large number of fish found to be available observed during collections. The normal ranges of haematolgoical indices has been studied in the neo tropical fish, Corydoras paleatus (Jimena et al., 2005) from an unpolluted area and reported that hemoglobin is a key parameter to point out differences between population and different environmental conditions and it could be used as biomarkers in future works evaluating the incidence of environmental stress on fish as well as pointing out charges in the water quality. 
Hematocrite provides measurements of red blood cells (Erythrocytes) in whole blood while hemoglobin within those erythrocytes is the main transport mechanism for oxygen and carbon dioxide. The decrease in the hemoglobin and hematocrite may be because of less number of erythrocytes. In the present study the fish, N.notopterus collected from Bheema river found to have normal levels of all the blood parameters studied and this may be due to proper amount of dissolved oxygen and normal temperature and food availability. The other indices which are commonly used are mean cell volume (MCV), mean corpuscular hemoglobin $(\mathrm{MCH})$ and mean corpuscular hemoglobin concentration (MCHC) are also found to be normal and this is because of proper number of erythrocyte count.

Serum biochemical parameters can be used for confirming the maturity and monitoring any charges in the quality of water and related soils (Satheesh kumar et al., 2010). The glucose concentration depends on the fish life mode and particularly on its locomotive capacity (Carneiro and Amarel, 1979). Baldisseroto (2002) reported that fish with omnivorous habits are often exposed to natural food with variable quantity of carbohydrates. They need to be capable of regulating the glucose absorption according to its available quantity in the food. The glucose levels found in the fish, N.notopterus in the present study is normal, since the fish, N.notopterus is omnivorous and often exposed to natural food with good amount of carbohydrates. The total serum protein levels of the fish, N.notopterus was found to the marginally lower. The inter-species variation in total serum protein levels has been reported for L.macrocephalus and P.lineatus during intensive culture (Tavares-Dias et al., 2008) and suggested that low level of total protein may occur in consequence of alimentary restriction.

The blood of fish contains urea and the liver being the primary organ of production the gills appearing to be the main organ of excretion (Walsh et al., 2003). The elevated level of blood urea nitrogen (BUN) is probably not indicative of renal disease in the fish (Mensinger et al., 2005). However, it is more likely associated with gill or liver disease. In the present study, the fish, N.notopterus collected from Bheema river the, BUN level found to be normal indicating that the fish is healthy without any sign of gill or liver damage.

Electrolyte $\left(\mathrm{Na}^{+}, \mathrm{K}^{+}, \mathrm{P}^{+}\right.$, and $\mathrm{Ca}^{++}$levels indicate the operation of a variety of homeostatic mechanisms in the body (Clarke, 1998). Monovalent ions namely, sodium $\left(\mathrm{Na}^{+}\right)$, and potassium $\left(\mathrm{K}^{+}\right)$play an important role in osmoregulation and homeostasis. In vertebrates, the $\mathrm{Na}^{+}$ concentration in the extracellular fluid surpasses that in the cytosol whereas $\mathrm{K}^{+}$is higher in the intracellular fluid compared to the plasma. Thus, the levels of serum electrolytes offer important knowledge concerning the health status of diseases of and impact of stress on fish (Wurst and Stickney,1989; Evans,1993).

\section{Acknowledgement}

The author R.S. Kulkarni is grateful to University Grants Commission, New Delhi for selecting Emeritus fellowship (2014-15 batch/starting from feb.2015) under which the work was carried out. The author is also thankful to Gulbarga University for providing laboratory facilities.

\section{References}

[1] Baker, F. J., \& Silverton, R. E. (1976). Introduction to medical laboratory technology. London: $6^{\text {th }}$ Ed. Butterworths.

[2] Baladisseroto B (2002) Fisiologia de peixes aplicada a piscicultura. Santa Maria Editora UFSM,211.

[3] Carneiro, N.M and Amaral,A.D (1979). The normal blood sugar of pimelodels maculates (lace'pe'da,1803)(pisces Teleoski) comparision between o-foluidine and glucose-oxidase methods.Boletim de Fisiologia Animal Universidade de sao Paulo,v. 
[4] Chekrabarthy,P and Benerjee,V.(1988). Effects of sublethal toxicity of three organo phosphorus pesticide on the peripheral haemogram of the fish ,channa punctatus,Envioron.Ecol.6:151-158.

[5] Dacie,J.V and Lewis ,S.N(1984). Practical Haematology $6^{\text {th }}$ Edition,Edinberg,Churchill livingstone.

[6] Clarke, F. (1998). A review of the scientific justifications for maintaining the cetaceans in captivity. A report for the Whale and Dolphin Conservation Society (WDCS).

[7] Evans, D.H. (1993). The Physiology of Fishes. $2^{\text {nd }}$ Edn., CRC press, Boca Raton, pp: 49-73.

[8] Fagbenro, O. A. (2002). Tilapia: fish for thought. 32nd Inaugural Lecture, Federal University of Technology, Akure, Nigeria. 77pp.

[9] Fauseh,K.D, Leons,J., Karr,R. and Angermeier P.L(1990). Fish communities as indicators of environmental degredation. American fisheries society symp., 8:123-144.

[10] Iwama,G.K., Greer,G.L and Larkin D.A(1976) changes in some haematological characteristics of coho salmon (oncorlynclus Kisutch) in respone to acute exposure to dehydroacietic acid (DHAA) at different exercise levels.J.Fish Res.BD.can., 33:285-289.

[11] Jimena, C., Daniel, A.W., Andres, C.H. and Maria de los, A.B.(2005). Hematological parameters in a neotropical fish, Corydoras paleatus (jenyns, 1842) (pisces, Callichthyidee), captured from pristine and polluted water, Hydrobiologia,537:25-33.

[12] Kalashnikova, Z.M. (1976). On the classification of morphological elements in the blood of fish. J. Ichthy., 3(16): 459-472.

[13] Lawrence M.S(1986),Amino acids and proteins .In: Textbook of clinical chemistry Tiezt,N.A(editor) W.B. Sounders company, US. p.519-618.

[14] Mensinger,A.F., Patrick,J.W and Roger T.H.(2005). Blood chemistry of the Oystr Toad fish of Aquatic Animal Health, 17:170-176.

[15] Percin, F., Sibel, K., Kursat, F and Sahin, S. (2010). Serum electrolytes of wild and captive Bluefin Tuna (Thunnus thynnus L.) in Turkish Seas J. Anim. Vet. Adv. 9(16): 22072213.

[16] Ross, B. and Ross, L.G. (2002). Anaesthetic and Seductive for Aquatic Animals.2 ${ }^{\text {nd }}$ Edition, Blackwell Science Ltd.

[17] Satheesh kumar,P., Senthil kumar,D,Ananthan,G., Soundara pandian ,P. and Anisa,B.(2010).Measurement of haematological and biochemical shedies on wild marine carnivorous of India,comp.clin.Pathol.DoI 10.1007/500580-010-0966-9.

[18] Tavares-Dias,M.,Moraes,F.R., Imoto,M.E.(2008).Haematological parameters in two neotropical freshwater teleost,Leporinus macrocephalus (Anostomidae) and Prochilodus lineatus (Prochilodontidal).Bioscience journal,24:96-101.

[19] Walsh,D.J.,Mayer,G.D.,Medina,M.,Bernstein,M.L.,Barimo,J.F.,Momsmsen,T.P. (2003). A second glucamine synthetase gene with expression in the gills of the gulf toad fish (opasanus beta).J. Exp.Biol.,206, 1523-1533

[20] Wurst, W.A. and R.R. Stickney, (1989). Responses of red drum (Sciaenopso cellatus) to calcium and magnesium concentrations in fresh and salt water. Aquaculture, 76: 21-35. 